\title{
"Error But Without Malice" in Defamation of Public Officials: The Value of Free Expression in International Human Rights Law
}

\author{
Edward L. Carter \\ Brigham Young University, ed_carter@byu.edu
}

Follow this and additional works at: https://scholarsarchive.byu.edu/facpub

Part of the Communication Commons

\section{Original Publication Citation}

Edward L. Carter (2016) “Error But Without Malice” in Defamation of Public Officials: The Value of Free Expression in International Human Rights Law, Communication Law and Policy, 21:3, 301-322, DOI: 10.1080/10811680.2016.1184910

\section{BYU ScholarsArchive Citation}

Carter, Edward L., "'Error But Without Malice" in Defamation of Public Officials: The Value of Free Expression in International Human Rights Law" (2016). Faculty Publications. 4798.

https://scholarsarchive.byu.edu/facpub/4798 
"Error But Without Malice" in Defamation of Public Officials:

The Value of Free Expression in International Human Rights Law

Edward L. Carter, Professor of Communications

Brigham Young University

Government officials in various parts of the world use defamation to silence critics, but defamation liability may curtail freedom of expression on topics of public interest and undermine human rights generally. Article 19 of the International Covenant on Civil and Political Rights guarantees freedom of expression unless a state can show need to protect individual reputation and acts proportionally. In its adjudication of complaints for violations of Article 19, and in its General Comment 34, the United Nations Human Rights Committee has crafted the principle that defamation liability may not be imposed if an erroneous statement about a public official was made in "error but without malice." Although soft law, General Comment 34 represents the Committee's most compelling articulation of the values animating freedom of expression in international human rights law, and chief among the values is the role played by free expression to promote realization of all human rights.

After Angolan journalist Rafael Marques de Morais accused the nation's autocratic president of corruption in three newspaper articles in 1999, Marques was arrested at gunpoint, jailed for 40 days and tried for criminal defamation. ${ }^{1}$ Marques was convicted of criminal defamation and another crime under Angolan law called abuse of the press based on "offensive words and expressions" against President José Eduardo dos Santos. ${ }^{2}$ A judge ordered Marques to pay a fine and spend six months in prison; although the prison time was suspended, authorities prevented Marques from leaving the country for a time. The judge also ordered Marques' lawyer disbarred after the lawyer protested the judge's decision not to allow presentation of evidence that Marques made the accusations against dos Santos in good faith, believing them to be true. ${ }^{3}$

\footnotetext{
${ }^{1}$ Rafael Marques de Morais v. Angola (Communication No. 1128/2002), IIII 2.1-2.10, UN Doc CCPR/C/83/D/1128/2002 (2005).

${ }^{2} I d$. at $\mathrm{I}$ 2.10.

${ }^{3}$ Id. at TIII 2.8-2.10.
} 
On appeal, the Supreme Court of Angola reversed the criminal defamation conviction but affirmed the abuse of press conviction notwithstanding the freedom of expression provision in the nation's Constitution. ${ }^{4}$ The Supreme Court concluded Marques had harmed dos Santos' rights to honor and reputation and had failed to give him due respect as President. ${ }^{5}$ Marques submitted a complaint to the United Nations Human Rights Committee, which concluded that Angola violated Marques' freedom of expression right under Article 19 of the International Covenant on Civil and Political Rights (hereinafter "ICCPR"). Among other things, the Committee stated that dos Santos is "a public figure who, as such, is subject to criticism and opposition."

However, although Angola bound itself to the provisions of ICCPR by acceding to the treaty in 1992 with no reservations, ${ }^{7}$ the country seems not to have fully complied with the Human Rights Committee decision. Angola did pass a law in 2010 purporting to guarantee free expression, but the country continued to prosecute and imprison journalists who reported accusations against dos Santos and other government officials. In 2014 seven Angolan military generals and their fellow diamond-mining company board members brought claims against Marques for defamation. ${ }^{8}$ The charges stemmed from Marques' 2011 book Blood Diamonds: Torture and Corruption in Angola, in which he asserted that the Angolan military and a private security firm tortured hundreds of people, killing 100, in

\footnotetext{
${ }^{4}$ Id. at II 2.12 .

${ }^{5} \mathrm{Id}$.

${ }^{6} I d$. at $\mathbb{I I} 6.8$.

${ }^{7}$ United Nations, Treaty Collection, https://treaties.un.org/pages/viewdetails.aspx?chapter=4\&src=treaty\&mtdsg_no=iv-4\&lang=en (last visited March 31, 2015).

${ }^{8}$ Anonymous, Trial of Rafael Marques de Morais to begin on December 15, MAKAANGOLA.ORG (December 8, 2014), http://makaangola.org/index.php?option=com_content\&view=article\&id=11507:trial-of-rafaelmarques-de-morais-to-begin-on-15-december\&catid=28:direitos-humanos\&Itemid=230\&lang=en (last visited December 15, 2014).
} 
a single 18-month period in the country's diamond-mining district. ${ }^{9}$ Marques faced eight counts of criminal libel based on his demands for criminal investigation of the generals' conduct. ${ }^{10}$ Then, in 2015, prosecutors added 15 new defamation charges against Marques. ${ }^{11}$ Ultimately the judge ordered Marques to cease distribution of his book and gave him a sixmonth suspended jail sentence. ${ }^{12}$

Marques' case is not the only one in which a government critic has faced charges of defamation brought by government officials. ${ }^{13}$ But given Marques' accusations of government-backed torture and murder, his case illustrates particularly well the role played by free expression to promote all human rights. Former UN Human Rights Committee member and Professor Michael O’Flaherty has stated that criminal defamation laws in 160 nations represent a threat to freedom of expression, which he called "essential to the good working of the entire human rights system." ${ }^{14}$ International human rights law attempts to balance freedom of expression with other values, including individual dignity and reputation, public order, non-discrimination and respect for religious identity. Yet even so, curtailing free expression may not serve the interest of human rights generally.

\footnotetext{
${ }^{9} \mathrm{Id}$.

${ }^{10} I d$.

${ }^{11}$ Anonymous, A Day in Court, MaKaAngOLA.ORG (March 26, 2015), http://makaangola.org/index.php?option=com_content $\&$ view=article \&id=11558\&Itemid=230\&lang=en $($ last visited March 31, 2015).

12 David Smith, Angolan journalist given suspended jail term over blood diamonds book, THEGUARDIAN.COM (May 28, 2015), http://www.theguardian.com/world/2015/may/28/angolan-suspended-jail-blood-diamondsrafael-marques-de-morais (last visited November 1, 2015).

${ }^{13}$ Anonymous, Singapore defamation case threatens press freedom, AMNESTY INTERNATIONAL.ORG (November 19, 2009), http://www.amnesty.org/en/news-and-updates/news/singapore-defamation-casethreatens-press-freedom-20091119 (last visited December 16, 2014); Anonymous, Leading Opposition Broadcaster [in Honduras] Facing Criminal Libel Charges, REPORTERSWITHOUTBORDERS.ORG (August 27, 2014), http://en.rsf.org/honduras-leading-opposition-broadcaster-27-08-2014,46853.html (last visited December 16, 2014).

${ }^{14}$ Michael O'Flaherty, Freedom of Expression: Article 19 of the International Covenant on Civil and Political Rights and the Human Rights Committee's General Comment No. 34, 12(4) HuM. RigHTS L. REV. 627, 630631 (2012).
} 
The Human Rights Committee took a significant step in 2011 when it published General Comment 34 on Article 19. General Comments are not binding international law but they do provide important guidance and interpretation. General Comment 34 articulates the values behind freedom of expression in international human rights law, and the dominant value is to promote realization of all other human rights. In General Comment 34, the Committee expressed its view that Article 19 prohibits nations that are parties to ICCPR from imposing defamation liability for erroneous statements about public officials made without malice. ${ }^{15}$ For an American audience familiar with New York Times Co. v. Sullivan, ${ }^{16}$ it is important to note that the Human Rights Committee's rule may appear related to actual malice but the Committee neither used that phrase nor invoked Sullivan directly.

This article first traces the development of free expression, including limitations for protection of reputation, in the drafting history or travaux préparatoires of ICCPR's Article 19. In tracing that development, the article focuses on articulation of the values of free expression. The article then explains the role and importance of the Human Rights Committee as the treaty body within the UN system to monitor and ensure compliance with ICCPR. Among the Committee's tools are General Comments and jurisdiction to resolve individual complaints stemming from nations - referred to as "states parties" - that have signed and ratified ICCPR. The article then analyzes the Committee's recent expanded articulation of free-speech values, as well as the standard for the fault element of defamation, in General Comment 34 and individual complaint resolutions.

${ }^{15}$ UN Human Rights Committee, General Comment 34, CCPR/C/GC/34, II 47 (2011) [hereinafter GC 34]. 16376 U.S. 254 (1964). 
The article concludes that the free-speech values of ICCPR's Article 19 are unique to international human rights law, as is the "error but without malice" standard of General Comment 34. Although the Article 19 freedom of expression right is not the same as freedom of expression under the U.S. Constitution's First Amendment or any other particular national standard, the Article 19 right — as explained and strengthened by General Comment 34 and recent Human Rights Committee decisions - is nonetheless critical to the international human rights law enterprise. The Article 19 right deserves respect and adherence by the 168 states parties to ICCPR, and particular attention should be paid to how free expression serves the purposes of international human rights law generally.

\section{DEVELOPMENT OF FREEDOM OF EXPRESSION IN ARTICLE 19 ICCPR}

In the context of the U.S. First Amendment, scholars and jurists have highlighted the role played by free expression to enable the search for truth in a hypothetical marketplace of ideas, ${ }^{17}$ facilitate self-governance in a democratic society, ${ }^{18}$ serve as a counter-majoritarian check on the abuse of power by the government or other forces, ${ }^{19}$ promote tolerance, ${ }^{20}$ create a safety valve that fosters societal stability ${ }^{21}$ and allow individuals to exercise autonomy and experience self-realization. ${ }^{22}$ These values were canonized in Justice William J. Brennan's opinion for the U.S. Supreme Court majority in

\footnotetext{
${ }^{17}$ Abrams v. United States, 250 U.S. 616, 630 (1919) (Holmes, J, dissenting)

18 Alexander Meiklejohn, The First Amendment Is An Absolute, 1961 SuP. CT. REV. 245, 256 (1961).

${ }^{19}$ See Vincent Blasi, The Checking Value in First Amendment Theory, 1977 AM. BAR FOUND. RES. J. 521,527 (1977).

${ }^{20}$ LeE C. BOllinger, ThE TOLERANT SOCIETy 120 (1988).

${ }^{21}$ See THOMAS EMERSON, THE SYSTEM OF FREEDOM OF EXPRESSION 7 (1970).

${ }^{22}$ See David A.J. Richards, Free Speech and Obscenity Law: Toward a Moral Theory of the First Amendment, 123 U. PA. L. REV. 45, 62 (1974).
} 
Sullivan. ${ }^{23}$ Yet these are not the only possible free-expression values, as evidenced in the development of international human rights law.

One of the first goals of the United Nations after its establishment in 1945 was creation of a comprehensive statement of fundamental human rights. The UN Economic and Social Council adopted a resolution in 1946 that authorized the UN Commission on Human Rights to draft an International Bill of Rights. ${ }^{24}$ It is clear that freedom of expression was prominently contemplated because the Commission on Human Rights was empowered to constitute a Sub-Commission on Freedom of Information and of the Press. ${ }^{25}$ Eventually, a Drafting Committee for the International Bill of Rights was formed, and that group studied then-existing freedom of expression provisions of numerous nations as well as proposals by non-government organizations (NGOs).

The Drafting Committee in 1947 proposed a three-part free expression right. First, Article 15 of the proposed International Bill of Rights contained an absolute right regarding opinion: "Everyone has the right to form, to hold, to receive and to impart opinions."26 Second, Article 16 addressed freedom of information: "There shall be free and equal access to all sources of information both within and beyond the borders of the State."27 Third, Article 17 proposed a limited right that seemed to focus on mass media expression: "Subject only to the laws governing slander and libel, there shall be freedom of speech and of expression by any means whatsoever, and there shall be reasonable access to all channels

\footnotetext{
${ }^{23} 376$ U.S. at 269 (citations omitted).

${ }^{24}$ UN Economic and Social Council, Resolution 9(II), $2^{\text {nd }}$ Session (June 21, 1946), http://www.un.org/depts/dhl/udhr/meetings_1946_2nd_esc.shtml (last visited March 30, 2016).

${ }^{25} I d$.

${ }^{26}$ UN Commission on Human Rights, Drafting Committee, Draft Outline of International Bill of Rights, E/CN.4/AC.1/3 (June 4, 1947), at 6, http://www.un.org/en/ga/search/view_doc.asp?symbol=E/CN.4/AC.1/3 (last visited March 30, 2016).

${ }^{27} I d$.
} 
of communication. Censorship shall not be permitted." 28 A fourth provision, in Article 18, did not specify a right but rather a responsibility: "There exists a duty towards society to present information and news in a fair and impartial manner." 29

The Drafting Committee noted language from various national constitutions, among other sources, that explained rationales for freedom of expression. ${ }^{30}$ While many of the national provisions contained straightforward statements of the right without explanation, others explicitly discussed the values behind freedom of expression. For example, language from Liberia invoked the idea that "liberty of the press is essential to the security of freedom in a state." 31 A provision from Norway specifically protected expression "on the administration of the State...." ${ }^{32}$ In addition, a submission by a U.S.-based NGO emphasized that "[f]reedom of expression and association is vital to the preservation of the basic liberties...." and that all human rights could have "tangible meaning and practical application" only if government did not unduly censor communication. ${ }^{33}$

By the time the Drafting Committee made another report to the Commission on Human Rights in mid-1948, the Committee had considered a long list of restrictions on free expression that were proposed during the May 1948 UN Conference on Freedom of Information in Geneva. Conference participants suggested, among others, a limitation be imposed on freedom of expression for defamation but only if the defamatory statements did

\footnotetext{
${ }^{28} I d$.

${ }^{29} I d$.

${ }^{30}$ Drafting Committee of Human Rights Commission, International Bill of Rights Documented Outline Part 1 (June 11, 1947), E/CN.4/AC.1/3/ADD.1, at 117-136, http://www.un.org/en/ga/search/view_doc.asp?symbol=E/CN.4/AC.1/3/Add.1 (last visited March 30, 2016).

${ }^{31} \mathrm{Id}$. at 129.

${ }^{32} \mathrm{Id}$. at 132 .

${ }^{33} I d$. at $135-36$.
} 
not benefit the public. ${ }^{34}$ Around this same time the Drafting Committee considered language from the Soviet Union that freedom of expression should be protected "[i]n accordance with the principles of democracy and in the interests of strengthening international co-operation and world peace...."35

Ultimately the Drafting Committee's work led to adoption of both Article 19 in the Universal Declaration of Human Rights and Article 19 in ICCPR. When the UDHR was adopted on December 10, 1948, the UN General Assembly opted for a straightforward statement of the right to free expression in a single article that contained no elaboration of either underlying values or restrictions: "Everyone has the right to freedom of opinion and expression; this right includes freedom to hold opinions without interference and to seek, receive and impart information and ideas through any media and regardless of frontiers." ${ }^{36}$

The Universal Declaration, though, was not a treaty and thus had no binding force. Therefore, even after 1948 progress continued toward a draft International Covenant on Human Rights. By 1950, the draft free expression provision for the International Covenant left off the language about defamation and other exceptions and instead simply stated that limitations on freedom of expression must be "provided by law and necessary ... for the protection of the rights, reputation or freedoms of other persons. ${ }^{" 37}$ Two years later, the language was altered slightly to say that the limitation must be "provided by law and ... strictly necessary, in a democratic society ... for the respect of the rights and reputations of

\footnotetext{
${ }^{34}$ UN Drafting Committee of Commission on Human Rights, Second Session, Report (May 21, 1948), E/CN.4/95, at 31, http://www.un.org/en/ga/search/view_doc.asp?symbol=E/CN.4/95 (last visited March 30, 2016).

${ }^{35} \mathrm{Id}$. at 30 .

${ }^{36}$ Universal Declaration of Human Rights, Article 19, adopted Dec. 10, 1948, UNGA Res. 217 A(III).

${ }^{37}$ MARC J Bossuyt, GUIDE TO THE ‘TRAVAUX PRÉPARATOIRES' OF THE INTERNATIONAL COVENANT ON CIVIL AND POLITICAL RightS 388 (1987).
} 
others. ..."38 The same year, 1952, the Commission on Human Rights eliminated reference to a democratic society. ${ }^{39}$ By 1961, the UN General Assembly had crafted the final language of the free expression provision, and it officially became Article 19 of ICCPR when that Covenant was adopted on December 16, 1966:

1. Everyone shall have the right to hold opinions without interference. 2. Everyone shall have the right to freedom of expression; this right shall include freedom to seek, receive and impart information and ideas of all kinds, regardless of frontiers, either orally, in writing or in print, in the form of art, or through any other media of his choice.

3 . The exercise of the rights provided for in paragraph 2 of this article carries with it special duties and responsibilities. It may therefore be subject to certain restrictions, but these shall only be such as are provided by law and are necessary:

(a) For respect of the rights or reputations of others;

(b) For the protection of national security or of public order (ordre public), or of public health or morals. ${ }^{40}$

The content of the third paragraph of Article 19 was debated in the Commission on

Human Rights for several years. One side argued that specifying duties and responsibilities of individuals was not the purpose of an international agreement on civil and political rights and therefore should not be included. ${ }^{41}$ However, that argument did not prevail in light of the counter-argument that the effect of modern media expression would be so great that an emphasis on duties and responsibilities was needed. ${ }^{42}$

In summary, the travaux préparatoires of Article 19 ICCPR illustrate that drafters considered freedom of expression to serve various values in society but primary among those was to ensure other human rights and facilitate the functioning of the human-rights

\footnotetext{
${ }^{38} \mathrm{Id}$. at $389-390$.

${ }^{39} \mathrm{Id}$. at 401.

${ }^{40}$ International Covenant on Civil and Political Rights, Article 19, adopted Dec. 19, 1966, entered into force Mar. 23, 1976, 999 U.N.T.S. 171 [hereinafter ICCPR].

${ }^{41}$ BossuYT, supra note 37 at 386.

${ }^{42}$ Id. at 386-87.
} 
system. Although the final version of Article 19 ICCPR omitted explicit reference to the public interest in allowing certain defamations of public officials, the provision does require that any restriction on freedom of expression for defamation be "provided by law" and "necessary." 43 This test aims ensures that the means employed by government are proportional to the goal sought. Therefore, Article 19 requires that any limitation on freedom of expression actually be effective to achieve the state's objective and be no more broad than necessary.

Today, ICCPR is the most prominent of nine international human rights law treaties administered by the United Nations. The other treaties are the International Convention on the Elimination of All Forms of Racial Discrimination; the International Covenant on Economic, Social and Cultural Rights; the Convention on the Elimination of All Forms of Discrimination Against Women; the Convention Against Torture and Other Cruel, Inhuman or Degrading Treatment or Punishment; the Convention on the Rights of the Child; the International Convention on the Protection of All Rights of Migrant Workers and Members of Their Families; the International Convention for Protection of All Persons From Enforced Disappearance; and the Convention on the Rights of Persons With Disabilities.

The remainder of this article discusses how Article 19 of ICCPR, the freeexpression provision, has become the linchpin for human rights contained not only in ICCPR but in the other international human-rights law treaties as well. It is important to note that ICCPR has 168 states parties (i.e. nations that have both signed and ratified the treaty), and it is one of only three of the UN human-rights treaties - along with the treaties on racial discrimination and torture, respectively — that has been both signed and ratified by

\footnotetext{
${ }^{43}$ ICCPR art. 19.
} 
the United States. ${ }^{44}$ Enforcement of each of the human-rights treaties mentioned above is overseen by a treaty body that issues regular reports about compliance by individual states parties and also adjudicates complaints of violations of treaty provisions. This article next turns to the role of the UN Human Rights Committee in defining the meaning of Article 19 of ICCPR.

\section{INTERPRETATION AND APPLICATION OF ARTICLE 19 BY THE HUMAN RIGHTS COMMITTEE}

As the treaty body charged with monitoring implementation of international humanrights law standards set forth in ICCPR, the Human Rights Committee (not to be confused with the policy-making UN Commission on Human Rights, now called the Human Rights Council) is called upon to interpret ICCPR, including Article 19. The Committee examines state reports and makes concluding observations that focus on freedom of expression, among other rights. In its jurisprudential role, the Committee hears disputes and makes determinations about whether states have violated rights guaranteed by Article $19 .{ }^{45}$ The Human Rights Committee and other treaty bodies are designed to be independent, which allows them to engage in vigorous scrutiny and to "contribute to the progressive development of international human rights law through authoritative interpretations of treaty provisions or advice to all stakeholders on thematic matters." 46

\footnotetext{
${ }^{44}$ UN Office of the High Commissioner for Human Rights, Status of Ratification Interactive Dashboard, http://indicators.ohchr.org/ (last visited March 30, 2016).

${ }^{45}$ UN Office of the High Commissioner for Human Rights, Civil and Political Rights: The Human Rights Committee (May 2005), http://www.ohchr.org/Documents/Publications/FactSheet15rev.1en.pdf (last visited March 31, 2015).

${ }^{46}$ Navi Pillay and Claudio Grossman, The International Human Rights Treaty System: Impact at the Domestic and International Levels, 21(1) HUM. RIGHTS BRIEF 32 (2014) (interview of Claudio Grossman by Megan Wakefield).
} 
The Human Rights Committee is made up of 18 experts who meet three times per year to consider state reports, issue concluding observations and also adjudicate individuals' complaints against nations that have signed ICCPR but are alleged to have violated its provisions. The Committee does have authority to monitor compliance with ICCPR and yet the Committee is not a judicial body and its members are not empowered to make international law. Whether the Committee's interpretations of ICCPR are authoritative is subject to debate, and while the Committee fills a quasi-judicial function, much of its work might best be considered "soft" international law. ${ }^{47}$

Still, the Human Rights Committee develops persuasive international human rights standards and provides thematic guidance through formulation and distribution of General Comments. General Comments may focus on a particular provision of ICCPR. The Human Rights Committee's practice of issuing General Comments dates to the early 1980s and stems from a charge given in Article 40(4) ICCPR. At first, General Comments were perceived as "essentially procedural and descriptive and therefore rather innocuous in character." ${ }^{48}$ But as the role of the Human Rights Committee and other UN treaty bodies has evolved from mere expert monitoring to quasi-administrative and even quasi-judicial, the role of General Comments has changed too. ${ }^{49}$ The Committee itself describes a General Comment as capturing "the Committee's conceptual understanding of the content of a

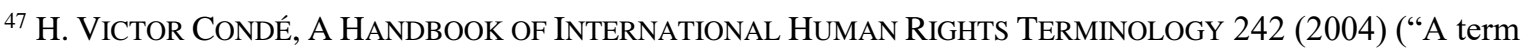
describing a doctrine of international law that describes the legal status of certain human rights related declarations, resolutions, guidelines, and basic principles. They are created . . . as nonbinding norms, setting forth nonobligatory but highly recommended standards of state conduct that should be followed.").

${ }^{48}$ Paula Gerber, Joanna Kyriakakis \& Katie O'Byrne, General Comment 16 on State Obligations Regarding the Impact of the Business Sector on Children's Rights: What Is Its Standing, Meaning and Effect?, 14 MELBOURNE J. OF INTL. L. 93, 99 (2013).

${ }^{49}$ UN Office of the High Commissioner, supra note 45 at 24-25.
} 
particular provision, and as such is a very useful guide to the normative substance of international human rights obligations. $" 50$

Although not binding, General Comments nonetheless have political, moral and even some legal weight. ${ }^{51}$ Their legal weight takes two forms: first, they may be considered, in some contexts, authoritative legal interpretations that states parties should comply with in good faith; second, General Comments are aspirational declarations of best practices - not necessarily restatements of what the law is but rather articulations of what it should be. ${ }^{52}$ Thus the power of General Comments lies in their normative statements, which are both informed by and reinforced through the Human Rights Committee's concluding observations on state reports and the Committee's jurisprudence. ${ }^{53}$

\section{General Comment 10 and Early Interpretations of Article 19}

When the Human Rights Committee adopted General Comment 10 in 1983, it made some superficial observations about Article 19 but details were "very scant." 54 The Committee did not address defamation explicitly, and it said with regard to limitations on freedom of expression only that the state "may not put in jeopardy the right itself." 55 General Comment 10 is only a page long and it did not specifically mention a right to criticize public officials.

Still, in a relatively early case under the ICCPR, the Human Rights Committee concluded that Uruguay violated the Article 19 rights of two citizens by imprisoning and

\footnotetext{
${ }^{50} I d$. at 24.

${ }^{51}$ Gerber et al., supra note 48 at 99-100.

52 Id. at 100-102; CONDÉ, supra note 47 at 96-97.

${ }^{53}$ UN Office of the High Commissioner, supra note 45 at 24-25.

${ }^{54}$ O'Flaherty, supra note 14 at 636.

${ }^{55}$ UN Human Rights Committee, General Comment 10: Freedom of expression, 29/06/1983.
} 
torturing them in the 1970 s for "subversive" political activities. ${ }^{56}$ Although Uruguay argued the Committee's airing of the allegations constituted defamation of the nation's character, the Committee concluded that both citizens and the international human-rights law system were entitled to scrutinize the conduct of government authorities. ${ }^{57}$ In 1992 , about a decade after adoption of General Comment 10, the Committee held that the Article 17 ICCPR reputation and honor rights of the former director general of Peruvian penitentiaries were not violated when newspapers and presidential campaign candidates accused him of corruption. ${ }^{58}$

In 1996 the Committee endorsed citizens' right to critique their government leaders. After examining claims by three Togolese men that they were jailed and their salaries docked for reading and sharing criticisms of the government, the Committee observed that "citizens must be allowed to inform themselves about alternatives to the political system/parties in power, and that they may criticize or openly and publicly evaluate their Governments without fear or interference or punishment. ..."59 Togo was found in violation of Article 19. The Committee decided in 2004 that a Sri Lankan journalist charged with defaming government ministers and police officials was entitled to remedies under Article 19 because Sri Lanka had repeatedly indicted the journalist and left some of the charges pending for years. ${ }^{60}$

\footnotetext{
56 Ann Maria Garcia Lanza de Netto v. Uruguay, Communication 8/1977, UN Doc CCPR/C/OP/1 at 45 (1984).

${ }^{57} I d$. at 16 (faulting the government of Uruguay for failing to provide evidence of the citizens' alleged subversive political activities).

${ }^{58}$ González del Río v. Peru, Communication 263/1987, UN Doc CCPR/C/46/D/263/1987 (1992).

${ }^{59}$ Adimayo M Aduayom, Sofianou T Diasso and Yawo S Dobou v. Togo, Communications 422/1990, 423/1990 and 424/1990, UN Doc CCPR/C/51/D/422/1990, 423/1990 and 424/1990 (1996).

${ }^{60}$ Victor Ivan Majuwana Kankanamge v. Sri Lanka, Communication 909/2000, UN Doc CCPR/C/81/D/909/2000 (2004).
} 
In one of its most detailed analyses of the Article 19(3) standard for restricting freedom of expression, the Committee in 2006 concluded that Serbia and Montenegro did not have sufficient justification for convicting a journalist of criminal insult. ${ }^{61}$ The journalist had accused a Socialist Party leader of corruption, and the Committee took particular note of the leader's public official status. The Committee said in Bodrožić v. Serbia and Montenegro that "in circumstances of public debate in a democratic society, especially in the media, concerning figures in the political domain, the value placed by the Covenant upon uninhibited expression is particularly high." ${ }^{.62}$ Thus the Committee suggested there is not a necessity, under Article 19(3), to protect the rights or reputations of public officials when the accusations leveled against them have a good-faith basis.

Even when it is unclear whether accusations against government officials have a good-faith basis, the Human Rights Committee has emphasized that the burden is on the state to prove restrictions on freedom of expression are necessary. In the case of a member of the Sri Lankan Parliament sentenced to two years of hard labor in prison for questioning the independence and integrity of the Sri Lankan Supreme Court, the Committee found a violation of Article 19. ${ }^{63}$ Although Sri Lanka argued the contempt conviction was necessary to protect the reputation of the court, the Committee stated that the need to maintain orderly court proceedings does not justify a court in insulating itself from all criticism. In this particular case, the state had no way to prove the falsity of the

\footnotetext{
${ }^{61}$ Mr Zeljko Bodrožić v. Serbia and Montenegro, Communication 1180/2003, UN Doc CCPR/C/85/D/1180/2003 (2006).

${ }^{62} \mathrm{Id}$. at $\mathbb{I}$ 7.2.

${ }^{63}$ Dissanayake, Mudiyanselage Sumanaweera Banda v. Sri Lanka, Communication 1373/2005, UN Doc CCPR/C/93/D/1373/2005 (2008).
} 
parliamentarian's statement, which was that the court might issue a "disgraceful decision" in a pending case. ${ }^{64}$

Contemporaneous with its decision in the Sri Lankan case, the Human Rights Committee in 2008 advised the United Kingdom, in concluding observations to a state report, to consider adopting a higher standard of fault for defamation. ${ }^{65}$ The Committee said it was concerned the UK's defamation law as it stood in 2008 "has served to discourage media reporting on matters of serious public interest. ..."66 Therefore, the Committee said, the UK should "require[e] proof by the plaintiff of actual malice in order to go forward on actions concerning reporting on public officials and prominent public figures. ..."67 Although the Committee did not reference the U.S. Supreme Court, the phrase "actual malice” obviously refers to Justice Brennan's majority opinion in Sullivan, which required that government officials suing for defamation prove that false statements were made with knowledge of falsity or reckless disregard for the truth. ${ }^{68}$ The Committee's jurisprudence prior to General Comment 34 demonstrated protectiveness for criticisms of public officials but lacked an explicit standard by which to measure the permissibility of those critiques when they included defamatory statements.

\section{General Comment 34}

\footnotetext{
${ }^{64} \mathrm{Id}$. at II 8.3 .

${ }^{65}$ Human Rights Committee, 93 ${ }^{\text {rd }}$ Session, Concluding Observations to report of the United Kingdom of Great Britain and Northern Ireland (July 30, 2008), CCPR/C?GBR/CO/6 at II 25, http://docstore.ohchr.org/SelfServices/FilesHandler.ashx?enc=6QkG1d\%2FPPRiCAqhKb7yhsg\%2FOK3H8q ae8NhIDi53MecK\%2F2gqd4WjxGafXAOvi2gd8MGnqbt1avQnaNolUy2XcvBwJ5RjyX8HLStgrG3Gvb212 L1D8aWEhetjn9vv7zgmO (last visited Dec. 22, 2014).

${ }^{66} \mathrm{Id}$.

${ }^{67} \mathrm{Id}$.

68376 U.S. 254 (1964).
} 
In 2009, the Human Rights Committee determined to replace General Comment 10 with a new interpretation of Article 19, and the Committee appointed O'Flaherty, who served on the Human Rights Committee from 2004 to 2012, as rapporteur. ${ }^{69}$ O’Flaherty later described four sources he used in creating the initial draft: General Comment 10; other relevant General Comments by the Committee; the Committee's jurisprudence; and Concluding Observations on state reports. ${ }^{70}$ O'Flaherty further explained that General Comment 34 is organized thematically but does not track the format of Article 19 itself, particularly when it comes to the grounds for restriction in Article 19(3). ${ }^{71}$

\section{Compared to the one page of General Comment 10, the Committee's General} Comment 34 reaches to 13 pages. By the time General Comment 34 was published in 2011, the Committee's use of General Comments had evolved to the point that each was considered "authoritative legal analysis of the provisions of the treaty"72 and "an autonomous and distinct juridical instrument." ${ }^{, 73}$ During the drafting of General Comment 34, states parties, scholars, NGOs and special rapporteurs submitted approximately 350 proposals. $^{74}$

A few scholars previously have analyzed General Comment $34 .^{75}$ Michael O'Flaherty's work is particularly valuable given that he was the rapporteur selected by the Human Rights Committee in 2009 to draft the text. O'Flaherty detailed the drafting

\footnotetext{
${ }^{69}$ O'Flaherty, supra note 14 at 645.

${ }^{70} \mathrm{Id}$. at 646.

${ }^{71} I d$. at 647.

${ }^{72}$ Id. at 644 .

${ }^{73}$ Alfred de Zayas and Áurea Roldán Martín, Freedom of Opinion and Freedom of Expression: Some Reflections on General Comment 34 of the UN Human Rights Committee, 59 NETHERLANDS INTL. L. REV. 425, 427 (2012).

${ }^{74}$ Remarks by Michael O'Flaherty, Limitations on Freedom of Opinion and Expression: Growing Consensus or Hidden Fault Lines?, 106 AM. SoC'Y OF INTL. L. PROCEEDINGS 347, 348 (2012).

75 O’Flaherty, supra note 14; de Zayas and Martín, supra note 73.
} 
process, providing insights about the meaning of the General Comment. ${ }^{76}$ One American scholar has suggested General Comment 34 established a binding international-law basis for freedom of access to government-held information. ${ }^{77}$ Other commentators have treated General Comment 34 as an interpretation of Article 19 that should be heeded but that may be supplemented with other interpretive devices. ${ }^{78}$

Much of the scholarly attention on General Comment 34 has been in the context of blasphemy laws. An American law student called General Comment 34 a "reinterpretation" of Article 19 that left the door open too wide for blasphemy laws, even while the same author praised General Comment 34 for advocating protection of some false speech as non-defamatory. ${ }^{79}$ In the context of blasphemy laws, General Comment 34 has been called a "formal statement" of international human rights law. ${ }^{80}$ In the area of protections for mass media and those accused of defamation, too, scholars have given weight to General Comment 34 and found its provisions worthy of analysis for their normative importance. ${ }^{81}$

In an early version of the General Comment presented to the Committee in January 2010, O'Flaherty referred to General Comment 25: Participation in Public Affairs and the Right to Vote. ${ }^{82}$ In a subsequent draft of June 2010, the General Comment 34 again

\footnotetext{
${ }^{76}$ O'Flaherty, supra note 14.

${ }^{77}$ Margaret B Kwoka, Deference, Chenery, and FOIA, 73 MARYLAND L. REV. 1060, 1062 n.6 (2014).

${ }^{78}$ Anjanette H Raymond, Heavyweight Bots in the Clouds: The Wrong Incentives and Poorly Crafted

Balances That Lead to the Blocking of Information Online, 11 NORTHWESTERN J. OF TECH. \& INTELL. PROP. L. 473 , *22 n.75 (2013).

${ }^{79}$ Caleb Holzaepfel, Can I Say That? How an International Blasphemy Law Pits the Freedom of Religion Against the Freedom of Speech, 28 EMORY INTL. L. REV. 597, 620-624 (2014).

${ }^{80}$ Ilias Trispiotis, The Duty to Respect Religious Feelings: Insights from European Human Rights Law, 19 COLUMBia J. OF EUROPEAN L. 499, 539 (2013).

${ }^{81}$ de Zayas and Martín, supra note 73.

${ }^{82}$ UN Human Rights Committee, Draft General Comment 34, CCPR/C/GC/34/CRP.2 If 20 (2010) [hereinafter GC 34 draft 2].
} 
included the reference to participation in public affairs and voting but added the following language that was eventually adopted in the final version: "The free communication of information and ideas about public and political issues between citizens, candidates and elected representatives is essential. This implies a free press and other media able to comment on public issues without censorship or restraint and to inform public opinion." $\$ 83$

In this matter, General Comment 34 evokes the early work by the Drafting Committee of the Human Rights Commission in 1947. Both the early documents and General Comment 34 endorse the concept that freedom of expression in a democratic society facilitates accountability of political leaders. The early draft of General Comment 34 specifically addressed political discourse and public debate about the performance of political figures. In this case, "the value placed by the Covenant upon uninhibited expression is particularly high." ${ }^{\prime 4}$ For this proposition, the January 2010 draft cited the Committee's 2006 decision in the Bodrožić v. Serbia and Montenegro case, which held that a journalist was protected by freedom of expression in accusing a Socialist Party leader of corruption. The reference to Bodrožić was preserved in subsequent drafts, including the final version. However, the language surrounding this citation was changed somewhat between the January 2010 and later versions.

The January 2010 draft, after citing Bodrožić, observed that mere insult to a public figure should not be legally actionable. ${ }^{85}$ Later versions, including the final draft, retained this statement but added the truism that "public figures benefit from the provisions of the

\footnotetext{
${ }^{83}$ UN Human Rights Committee, Draft General Comment 34, CCPR/C/GC/34/CRP.3 If 21 (2010) [hereinafter GC 34 draft 3].

${ }^{84}$ GC 34 draft 2 at $\mathbb{\text { II }} 37$.

${ }^{85} \mathrm{Id}$.
} 
Covenant," without elaborating. ${ }^{86}$ This addition could be seen as the Committee hedging somewhat on its commitment to freedom of expression, though in reality it only acknowledges the obvious fact that freedom of expression — even about public officials—is not absolute and may be curtailed under certain circumstances that are necessary and established by law, something Article 19(3) already makes clear.

In other ways, the Committee strengthened its statement of support for freedom of expression in the drafting process of General Comment 34. The January 2010 draft stated that "public figures, including heads of state, are legitimately subject to criticism and political opposition." ${ }^{87}$ As support for this statement, the draft cited the Committee's 2005 decision in favor of the Angolan journalist Marques, who accused the country's president of corruption and was charged with failing to duly respect the leader. In subsequent versions of General Comment 34, the reference to Marques was retained but the language accompanying the reference was changed slightly to read, "Moreover, all public figures, including those exercising the highest political authority such as heads of state and government, are legitimately subject to criticism and political opposition."${ }^{\circledR 8}$

In adding the word "all," the Committee seems to have desired to strengthen its statement about political leaders being subject to criticism. The word "all," in conjunction with addition of the phrase "those exercising the highest political authority," suggests a desire by the Committee to emphasize that no high political leader, regardless of the authority granted him or her, is exempt from opposition and critique. At the same time,

\footnotetext{
${ }^{86}$ UN Human Rights Committee, Draft General Comment 34, CCPR/C/GC/34/CRP.5 II 40 (2010) [hereinafter GC 34 draft 5].

${ }^{87}$ GC 34 draft 2 at II 37.

${ }^{88}$ GC 34 draft 5 at II 40.
} 
"all" suggests that even low-level and local government leaders should expect their performance to be scrutinized and publicly debated. In both the early and later versions of General Comment 34, O'Flaherty noted the Committee's jurisprudence disfavoring "lese majesty, desacato, disrespect for authority, disrespect for flags and symbols, defamation of the head of state and the protection of the honour of public officials. ..."

The early draft of General Comment 34 included a paragraph warning that defamation laws should "comply with the test of necessity in paragraph 3" of Article 19 so they would not "stifle freedom of expression." 90 Between January 2010 and November 2010, this sentence was altered slightly to say that defamation laws should "comply with paragraph 3" of Article 19, thus recognizing that restrictions on freedom of expression for defamation must not only be necessary in a democratic society but also must be stated in law. ${ }^{91}$ The broad reference to Article 19(3), in place of a specific mention of the test of necessity, also implicates the statement in Article 19(3) that exercise of the right to freedom of expression "carries with it special duties and responsibilities." Both early and later drafts emphasized that truth must be allowed as a defense to defamation, and that defamation liability should not be allowed for statements of opinion that are not capable of objective verification. $^{92}$

The key provision of General Comment 34, at least with respect to the fault requirement for defamatory statements about public officials, also underwent revision between the January 2010 and November 2010 versions. By November 2010, the language

\footnotetext{
${ }^{89} \mathrm{GC} 34$ at $\mathrm{II} 38$.

${ }^{90}$ GC 34 draft 2 at II 46.

${ }^{91} \mathrm{GC} 34$ draft 5 at $\mathrm{II} 49$.

${ }^{92}$ GC 34 draft 2 at II 46; GC 34 draft 5 at II 49.
} 
had evolved in favor of freedom of expression: "At least with regard to comments about public figures, consideration should be given to avoiding penalising or otherwise rendering unlawful untrue statements that have been published in error but without malice. In any event, a public interest in the subject matter of the criticism should be recognized as a defence."93 In both drafts, a citation was made to the Committee's concluding observations in the 2008 UK state report, in which the Committee recommended that the UK adopt the actual malice rule.

Although both the January 2010 and November 2010 versions of General Comment 34 stated only that states should give consideration to protecting erroneous statements made without malice, the November 2010 draft added the stronger statement that regardless whether a state adopts error but without malice as a standard, public interest should be a defense to defamation liability. ${ }^{94}$ Although public interest is not the same as error but without malice, it could function in much the same way, at least with respect to statements about the performance of government officials in their duties. Although the Committee did not state that a public interest defense was required by Article 19, General Comment 34 does say public interest "should" be a defense. ${ }^{95}$ Meanwhile, with respect to error but without malice, the Committee said only that "consideration should be given" to adopting the rule. ${ }^{96}$

It bears repeating that General Comment 34 does not use the phrase "actual malice." But paragraph 47 of the final version of General Comment 34 does cite to the Committee's

\footnotetext{
${ }^{93} \mathrm{GC} 34$ draft 5 at $\mathrm{II} 49$.

${ }^{94} \mathrm{GC} 34$ draft 5 at पITI $31,49$.

${ }^{95}$ GC 34 at IIII 19, 47.

${ }^{96} \mathrm{Id}$. at II 47.
} 
2008 concluding observations in the UK state report, and in those concluding observations the Committee did use the phrase "actual malice." The language the Committee used in General Comment 34 evokes the actual malice standard when it says states should consider protecting from defamation liability those "untrue statements that have been published in error but without malice." 97 Still, it is apparent that actual malice and error but without malice are not the same thing.

The early and later drafts of General Comment 34 differed in another significant way relating to defamation. The January 2010 version stated that criminalization of defamation "should only be countenanced in the most serious of cases" and that "imprisonment will rarely, if ever, constitute an appropriate penalty." 98 By November 2010, however, the final language had been adopted, and this was that "imprisonment is never an appropriate penalty." 99

\section{THE VALUES OF FREE EXPRESSION IN GENERAL COMMENT 34 AND SUBSEQUENT JURISPRUDENCE}

General Comment 34 reflects the values of freedom of expression. For example, General Comment 34 places "particularly high" value on "uninhibited expression" with respect to debate about political and other public issues. ${ }^{100}$ Human-rights tribunals have acknowledged this kind of debate may take place during a political campaign ${ }^{101}$ but it could also be in the context of a public discussion about the impact of corporate products on

\footnotetext{
${ }^{97} \mathrm{Id}$.

${ }^{98}$ GC 34 draft 2 at 1 [ 46.

${ }^{99} \mathrm{GC} 34$ draft 5 at 949.

${ }^{100} \mathrm{GC} 34$ at II 38.

${ }^{101}$ Ricardo Canese v. Paraguay, 2004 Inter-American Court of Human Rights (Ser. C) No 111, at II 69.1 (Aug. 31, 2004) (cited in Nicola Wenzel, Opinion and Expression, Freedom of, International Protection, in MAX PLANCK ENCYCLOPEDIA OF PUBLIC INTERNATIONAL LAW (April 2014)).
} 
health. ${ }^{102}$ General Comment 34 asserts that, sometimes, insult to public officials is necessarily protected in order to provide a check on government, allow self-governance and enable the search for truth. ${ }^{103}$

Perhaps the greatest contribution of General Comment 34 is its emphasis that protection of free expression is critical to preserve human rights generally. One of the first principles articulated in General Comment 34 is that free expression is necessary for transparency and accountability, which are in turn "essential for the promotion and protection of human rights." 104 According to the Committee, the "freedoms of opinion and expression form a basis for the full enjoyment of a wide range of other human rights" such as voting, assembly and association. ${ }^{105}$ One of the most important topics of discussion protected by Article 19 is human rights themselves. ${ }^{106}$ Although the drafters of General Comment 34 acknowledged that some limitations could be imposed on free expression in accordance with Article 19(3), those limitations should never be aimed at limiting the advocacy of human rights. ${ }^{107}$ Journalists were singled out for their role in free expression but so were human-rights workers and judges who enforced human-rights standards. ${ }^{108}$

Thus, although soft law, General Comment 34 is one of the most significant statements in international human rights law to define the purpose of free expression under ICCPR. Free expression in international human rights law not only enables the search for truth in the marketplace of ideas, facilitates democracy, provides a safety valve and serves

\footnotetext{
${ }^{102}$ Hertel v. Switzerland, Case 59/1997/843/1049, 1998 ECHR 77 (cited in Wenzel, supra note 101).

103 GC 34 at III $38,47$.

${ }^{104}$ GC 34 at II 3.

${ }^{105} \mathrm{Id}$. at II 4.

${ }^{106} \mathrm{Id}$. at II 11 .

${ }^{107} \mathrm{Id}$. at $\mathbb{} 23$.

${ }^{108}$ Id.
} 
as a check on government, but it also — and perhaps most importantly_ensures that all other rights - non-discrimination, food, health, freedom from torture or enforced disappearance and others - in the nine major human rights treaties can be realized. Here it is worth recalling the Nobel laureate Amartya Sen's much-discussed comment that "a free press and an active political opposition constitute the best early-warning system a country threaten [sic] by famines can have. ..."109

Subsequent to adoption of General Comment 34, the Committee in its resolution of complaints has cited General Comment 34's language regarding defamation and thus indicated its view on how states should apply Article 19. In 2012, the Committee concluded that the Philippines violated the Article 19 right of a radio broadcaster by punishing him for saying on the radio that a congressman had an inappropriate relationship with a married television personality. ${ }^{110}$ The Philippine trial court had held that the accusation of adultery amounted to a criminal allegation not related to the congressman's official duties and, therefore, was outside the protection of freedom of expression provisions. However, the Human Rights Committee disagreed with that narrow interpretation of freedom of expression and held that imprisoning the journalist was not in line with Article 19. In its decision, the Committee quoted the language from paragraph 47 of General Comment 34 that suggests statements about public officials should not be punishable if they are made with error but not malice. ${ }^{111}$

\footnotetext{
109 Amartya SEN, DeVElopment AS FreEdom 181 (1999).

${ }^{110}$ Alexander Adonis v. The Philippines, Communication 1815/2008, UN Doc CCPR/C/103/D/1815/2008/Rev.1 (2012).

${ }^{111}$ Id. at II 7.9 .
} 
The journalist received the information about the congressman's alleged adultery from three other credible Philippine news organizations, and the journalist attempted to contact the congressman and the TV personality without success. Under those circumstances, the journalist had a good-faith belief in the truth of the accusations because he did not have actual knowledge of their falsity and he did not have specific reason to believe they might be false. Even if he did not have direct and actual knowledge of the truth of the statement, the Human Rights Committee concluded that he could not be liable. In doing so, the Committee explicitly relied on the language from General Comment 34 that even untrue statements, made without malice and in the public interest, are protected free expression under Article 19. ${ }^{112}$

There is evidence that the Philippines may have acted counter to the spirit of the Human Rights Committee's decision. The Philippine journalist Adonis' lawyer, Harry Roque, decried the country's 2012 adoption of a Cybercrime Prevention Law which criminalized defamation and imposed a penalty of 6-12 years imprisonment. ${ }^{113}$ The Human Rights Committee seemed to have anticipated this possibility when, in its 2011 decision in the Adonis case, it warned that the Philippines had voluntarily agreed to the Committee's jurisdiction to resolve complaints made under ICCPR. ${ }^{114}$ Roque argued that the Philippines was bound under the doctrine of pacta sunt servanda to comply with ICCPR, including the free expression protections in Article 19. ${ }^{115}$

\footnotetext{
${ }^{112} \mathrm{Id}$

${ }^{113}$ Harry Roque, "Cybercrimes and Freedom of Expression," Sept. 20, 2012, at http://www.harryroque.com/?p=952 (last accessed April 9, 2016).

114 Adonis, supra note 110 at II 10.

${ }^{115}$ Roque, supra note 113. See CONDÉ, supra note 47 at 188 (describing pacta sunt servanda as "[a] general principle of international law that means that states must obey the treaties they have ratified. ... that treaties are legally binding obligations on states, and if a state fails to comply with a treaty ... then the state is in violation of this principle.").
} 
In November 2014 the Committee again cited General Comment 34 in holding that a state — this time Belarus — violated the Article 19 right of a citizen to publicly air allegations of corruption by elected political leaders. ${ }^{116}$ In this case, the man applied for a permit to hold a one-person picket in a pedestrian area but government officials denied his application, ostensibly on the basis that he would hinder traffic and disrupt public order. He contended before the Human Rights Committee that the assertions about hindering traffic and disrupting public order were pretexts and that the real reason for denial of his application was a desire by public officials to insulate themselves from criticism. The Committee agreed, recalling the purposes of freedom of expression under Article 19 to allow "for the full development of the person" and to ensure accountability of political leaders in a democracy. ${ }^{117}$ The Committee held that the state had failed to show the restriction on the man's freedom of expression was necessary and that the means employed in imposing the restriction were proportional to the end being served. ${ }^{118}$

The recent cases from the Philippines and Belarus illustrate the Human Rights Committee's commitment to the principle that citizens and journalists are entitled to criticize public officials. In the Belarus case, no citizen was punished for critical speech but the Committee made it clear that even preventing a citizen from accessing a forum to air grievances is in violation of Article 19. These cases demonstrate that the values of free speech embodied in General Comment 34 are being applied to foster self-governance,

\footnotetext{
116 Anatoly Stambrovsky v. Belarus, Communication 1987/2010, UN Doc CCPR/C/112/D/1987/2010 (2014). See also Pavel Levinov v. Belarus, Communications 1867/2009, 1936/2010, 1975/2010, 1977/2010, 1978/2010, 1979/2010, 1980/2010, 1981/2010 and 2010/2010, UN Doc CCPR/C/105/D/1867/2009, 1936, 1975, 1977-1981, 2010/2010 (2012).

117 Stambrovsky, supra note 116 at $\mathbb{1} 7.3$.

${ }^{118}$ Id.
} 
check on government and to enable other fundamental human rights. The cases analyzed in this article, beginning with the Human Rights Committee decision in the Uruguay case in 1984, stand for the proposition that the international human rights law system functions best when scrutiny of public officials is guaranteed.

\section{CONCLUSION}

In protecting speech about public officials, public figures and issues of public concern, the Human Rights Committee has been guided by the requirement in Article 19 that limitations on freedom of expression must be necessary and that the means chosen must be proportional to a legitimate and substantial end goal. ${ }^{119}$ Freedom of expression is vital to self-government, the search for truth, checking government power and allowing society to adapt and change with minimal violence. Protecting the reputation of government officials is also a legitimate government purpose, as recognized by General Comment $34 .{ }^{120}$ Yet the interest of public officials in being free from insult pales in comparison to the societal interests facilitated by freedom of expression, a reality also recognized by General Comment $34 .{ }^{121}$ The "error but without malice" standard strikes the balance in favor of freedom of expression.

The need for strong protection for speech about government officials continues in Angola, as in other states. Rafael Marques de Morais continues to be targeted by Angolan public officials and other powerful elites who are the subjects of his aggressive investigative journalism. Given the Human Rights Committee's previous decision in

\footnotetext{
${ }^{119}$ Nazila Ghanea, Expression and Hate Speech in the ICCPR: Compatible or Clashing?, 5 RELIGION \& HuM. RIGHTS 171 (2010).

${ }^{120} \mathrm{GC} 34$ at II 38 .

${ }^{121} I d$.
} 
Marques' favor, and now the additional guidance of General Comment 34, the recent prosecution and conviction of Marques raises substantial questions about violation of Article 19. His reporting comes in the context of an issue of public concern, and he has proven in the past to be thorough and careful in his research. If the military leaders could prove that he knew the charges were false or he recklessly disregarded their falsity, then Marques should be liable for defamation. But meeting that high standard of evidentiary proof is difficult. Short of evidence that he knew the information was false, punishing Marques is not proportional to the state's interest.

In future cases involving Marques or other critics of government officials, the Human Rights Committee could have opportunities to refine its standard for protection of freedom of expression. Protection for criticisms of public officials was a concern of the drafters of the UDHR and ICCPR, and it has continued to be a concern of the international human-rights law system ever since. Through Human Rights Committee jurisprudence and now General Comment 34, the standard has evolved into one that requires the defamation proponent to prove the speaker not only spoke in error but did so knowingly. This standard protects some false speech in the public interest, and the result is a more transparent and accountable system of government. This protection is, ultimately, a key to the entire human rights system. 